\title{
A Case Report on Bilateral Levator Glandulae Thyroidae
}

\author{
Dr. Padmaja Vasi M.B.B.S., M.D. \\ (Assistant Professor in Anatomy, Gandhi Medical College, Secunderabad - 500 025, Andhra Pradesh, India)
}

\begin{abstract}
During the routine undergraduate dissection of the Thyroid Gland of a sixty year old male cadaver in the department of Anatomy, Gandhi Medical College, it was observed that the presence of Levator Glandulae Thyroidae on both sides of isthmus of Thyroid Gland. This type of variation is observed only once in our study of about 150 specimens observed in Anatomy Department from 2004 to 2013, hence presented for its clinical importance.
\end{abstract}

Keywords - Levator Glandulae Thyroidae, Thyroid Gland, Isthmus

\section{INTRODUCTION}

Knowledge of morphological variations of the Thyroid Gland is essential for the surgeons in the region of the neck as it can mislead the diagnosis. It is also important for clinical beginners to have thorough knowledge of these variations because they often search for the gland too high in the neck. It should be palpated from behind the subject with the middle and index fingers lying just above the sternoclavicular joint across the trachea, as though spreading the converging sternomastoid muscles. Because of its facial attachments the gland moves upwards with swallowing and therefore, it slides under the examining fingers.

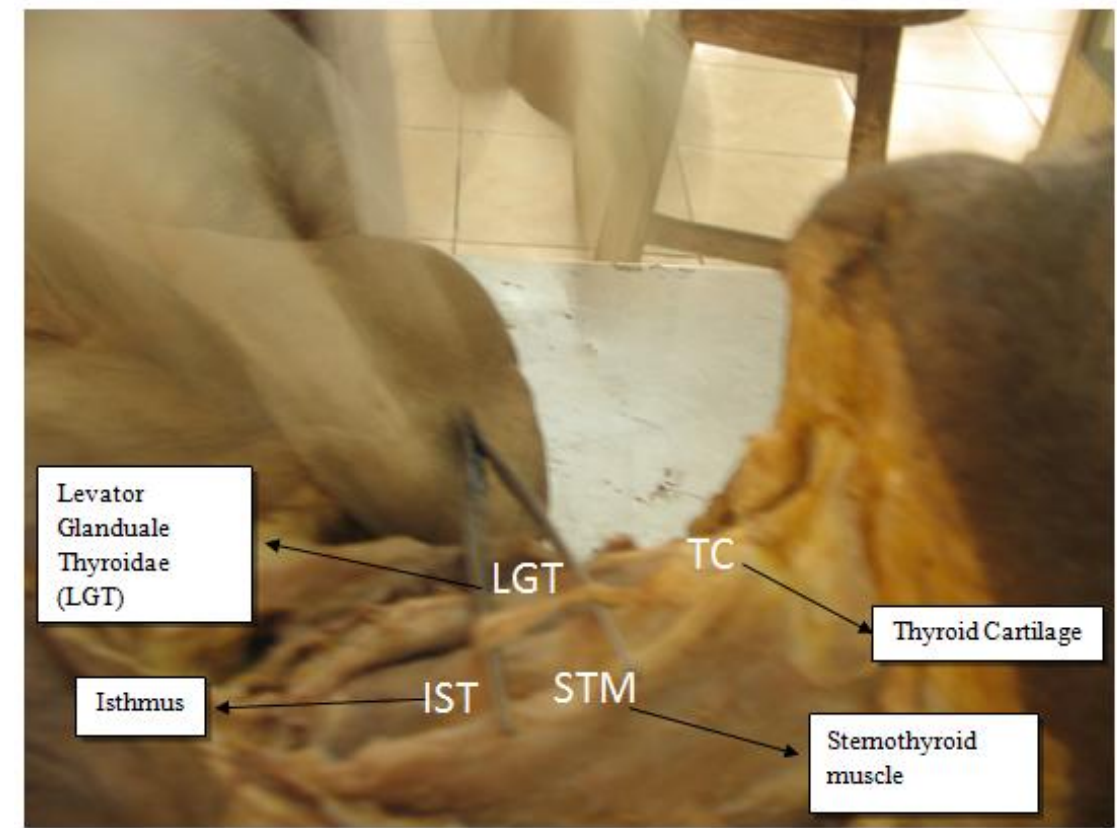

$$
\begin{aligned}
& \text { Fig- L- Bilateral Levator Glandulae Thyroidae; } \\
& \text { LGT: Levator Glandulae Thyroidae, TC: Thyroid Cartilage } \\
& \text { IST: Isthmus, STM: Stemothyroid muscle }
\end{aligned}
$$

Thyroid gland occupies an important position in the centre of the visceral compartment of the neck, lying astride the trachea just above the thoracic inlet. The gland has two lobes, shaped roughly like slender pears, hugging the antero lateral aspect of the cervical trachea from the level of thyroid cartilage to the $5^{\text {th }}$ or $6^{\text {th }}$ tracheal ring. The lobes are joined together across the midline by a thin isthmus. A variable sized pyramidal lobe arises from the isthmus somewhere along its upper border near the midline. Muscle fibres present in it are named as Levator Glandulae Thyroidae and they are innervated by external laryngeal nerve. [1] 


\section{CASE REPORT}

During the routine dissection in an adult male cadaver, it was observed that the presence of two fibrous bands without any muscle tissue extending upwards from the isthmus bilaterally and they are united to form a single fibrous band attached to the lower end of the thyroid cartilage as shown in Fig.1.

\section{DISCUSSION}

In comparison with the literature by earlier authors the present case study revealed an important variation of the Levator Glandulae Thyroidae which is entirely fibrous in nature without any pyramidal lobe and it is bilateral in origin and fused to form a single fibrous band attached to the thyroid cartilage. Moore and Persaud have stated the pyramidal lobe is seen $50 \%$ of population and the muscular band may be of smooth muscle fibres and that the pyramidal lobe and the associated muscle represents the persistant part of the distal end of the thyroglossal duct [2]. According to Gregory and Guse, Soemmerring's levator glandulae thyroidae is an accessory muscle which runs from the hyoid muscle to insert partly on the thyroid cartilage and partly on the isthmus of the thyroid gland [3]. Bourgey (1831) described and illustrated a muscle which he called as "hyothyroiden" which occupied the place of pyramidal lobe [4]. Godart (1847) reported a case in which the structure was indeed muscular on the basis of nitric acid test for the mucle. Soemmerring's muscle is same as the hyothyro-glandulaire of pointe, the levator glandulae thyroidae superficialis medius at longus of Krause and the musculus thyroiden of Merkel; its usual full name in the literature being levator glandulae of Soemmerring [5]. Huscheke (1845) spoke the structure only as glandular while he mentioned nothing about the muscle [6].

\section{CONCLUSION}

A thorough knowledge of thyroid anatomy and its associated anatomical variations are very much essential so that these anomalies are not over looked in the differential diagnosis of the neck pathologies and helps in better planning for safe and effective surgeries

\section{Acknowledgements}

I express my sincere thanks to our Professor and Head of the Department, Dr. Seema Madan, and Professor Dr. Sreelatha for their valuable suggestions and guidance. I am especially thankful to Dr. D.R. Manuva for her help in taking photographs. Finally, I would like to express my immense gratitude to my husban 1 iII M. Chandra Mouli for his invaluable support for editing and typing this case study and his constant encouragement throughout the duration of the study.

\section{REFERENCES}

[1] Lee McGregor's Synopsis of Surgical Anatomy $12^{\text {th }}$ Edition 1995 Verghese Publishing House, Bombay

[2] Moore KL, Persaud TVN., The developing human clinical oriented embryology $6^{\text {th }}$ Edition Philadelphia W.B. Sanders Company 2003; 203-3

[3] Gregory JK, Guse DM. Unique variant of levator glandulae thyroideae muscle. Clin Anat 2007; 20:966-7. Cited by Ranade AV, Rai R, Pai MM, Nayak SR, Prakash, Krishnamurthy A, Narayana S. Anatomical variation of the thyroid gland: possible surgical implications. Singapore Med J 2008;49:831-4.

[4] Bourgery JM. Traite complet d'anatomie de l'homme, comprenant la medecine operatoire, avec planches lithographiees d'apres nature par NH Jacob. Atlas. Paris. C. [-A.] Delaunay 1831; Tome II: 90, 1836; Tome IV: 91. French. Cited by Ranade AV, Rai R, Pai MM, Nayak SR, Prakash, Krishnamurthy A, Narayana S. Anatomical variation of the thyroid gland: possible surgical implications. Singapore Med J 2008;49:831-34.

[5] Godart J. Muscle de la glande thyroide, muscle de Duvernoi, musculus levator glandulae thyreoideae. (Exemple du Soemmerring.) [Abstr.] Bull Soc Anat Paris 1847; 22:202-5. French. Cited by Ranade AV, Rai R, Pai MM, Nayak SR, Prakash, Krishnamurthy A, Narayana S. Anatomical variation of the thyroid gland: possible surgical implications. Singapore Med J 2008;49:831-34.

[6] Huschke E. Traité de splanchnologie et des organes des sens. In: Encyclopedie Anatomique. Vol V. Paris: JB Bailliere, $1845: 274$. Cited by Ranade AV, Rai R, Pai MM, Nayak SR, Prakash, Krishnamurthy A, Narayana S. Anatomical variation of the thyroid gland: possible surgical implications. Singapore Med J 2008;49:831-34 